\title{
Does a successful future entrepreneur in the globalized world need to know logistics?
}

\author{
Šárka Čemerkováa, ${ }^{1,}$, and Žaneta Rylková2,* \\ ${ }^{1}$ Silesian University in Opava, School of Business Administration in Karviná, Department of Business \\ Economics and Management, Univerzitní náměstí 1934/3, Karviná, 733 40, Czech Republic \\ ${ }^{2}$ Silesian University in Opava, School of Business Administration in Karviná, Department of Business \\ Economics and Management, Univerzitní náměstí 1934/3, Karviná, 733 40, Czech Republic
}

\begin{abstract}
Starting a business entails huge demands on the future entrepreneur. Only a great idea and a desire to do business are not a guarantee of success. This future entrepreneur must be equipped with a wide range of knowledge, skills and personal qualities. These together form a set of business competencies. One area that clearly affects business success is logistics. Especially in today's globalized world, without logistics, realized on top professional level, it is not possible to succeed in a tough competitive environment. Large volumes of various materials (raw materials, materials, semi-finished products, products, goods, but also people) are moved practically all over the world. Poorly controlled material flow has a direct impact on the quality of provided customer service and thus on customer satisfaction. A dissatisfied customer equals no customer. The aim of the article is to provide the attitude of successful entrepreneurs in the Czech Republic to the issue of business competencies, specifically in the field of logistics. To what extent does the future successful entrepreneur need to know about logistics, resp. about their different forms? In the text, partial results of the primary research carried out in the winter of 2018-2019 in the Czech Republic will be presented. Questions about the competence in the field of logistics have been asked by entrepreneurs, whose business has existed for at least three years. The main conclusions will be given to the need for knowledge of distribution logistics for the future successful entrepreneur.
\end{abstract}

\section{Introduction}

Every person can hypothetically start a business. But is it really so? Will be anyone who wakes up in the morning and says, "I want to do business." really able to do business? Setting up a business, i.e. handling formal requirements, will not be the biggest problem. A real business will only start after that and it has huge demands on the future entrepreneur. Only a great idea and a desire to do business are not a guarantee of success. The future entrepreneur must be equipped with a wide range of knowledge, skills and personal qualities, i.e. be equipped with a range of competencies.

\footnotetext{
*Corresponding author : cemerkova@opf.slu.cz, rylkova@opf.slu.cz
} 
One area that clearly affects business success is logistics. In today's globalized world, an entrepreneur without logistics at the highest professional level cannot succeed. Competition is tough and the customer is uncompromising. One mistake is enough and the customer buys from the competition. And a competitor can be an enterprise from anywhere in the world. In the context of globalization, many new international trade and transport flows have emerged during the past decades. [1]

Logistics, especially distribution, has a major impact on customer satisfaction. She is responsible for ensuring that the customer receives what he ordered. There can be no question of a functioning customer service. Short delivery time is a feature that can influence consumers' purchasing decisions and that retailers compete over fiercely. [2] The findings show that overall service quality has a positive influence on customer satisfaction, which in turn leads to customer loyalty. [3] And in a supersaturated competitive environment, there is an effort to have as many loyal customers as possible.

It can therefore be assumed that basic knowledge of distribution logistics is one of the competences that a future entrepreneur should be equipped with. But is this assumption correct? How do successful entrepreneurs see this issue? The aim of the article is to provide an approach of successful entrepreneurs in the Czech Republic to the issue of entrepreneurial competences, specifically in the field of distribution logistics.

\section{Theoretical background}

Globalization is a long-term, complex process. It manifests itself in the area of economy, culture and politics. The movement of goods across the planet is expanding and accelerating through globalization. The International Monetary Fund lists international trade as one of the main aspects of globalization. [4]

International trade relies on perfectly functioning logistics. Distribution logistics is the link between production and the customer. And because their geographical distance can be considerable, functioning distribution logistics is a key factor in the success of all business.

In addition to the physical movement of goods (distribution), distribution logistics also includes processes for planning and managing the information flow. Its competence includes planning and management of physical realization of storage, handling, packaging or transport including their information security. Distribution structures include the spatial layout of freight transport and storage system used to move goods between production and consumption locations. [5]

Not every start-up entrepreneur has the ambition to realize itself on foreign markets. Which does not mean he will not have to deal with the tasks of distribution logistics. As the geographic distance increases, only the tasks of distribution logistics become more complex. Moreover, if an entrepreneur wants to operate on the market in the long term, then the given geographical distance can be expected to increase. Emphasizing on the customer experience and enhancing the value proposition to customers are undeniably vital factors for the long-term survival of any retail business. [6]

When starting a business entrepreneur will solve a variety of different problems. He cannot be an expert on everything, but he should be aware of this fact and make good use of outsourcing opportunities. Logistics is one of these problems. The logistics services industry has experienced enormous growth rate. [7] Logistics service providers offer a variety of complex solutions. Freight transport and distribution are based on various concepts and optimization models. [8]

Business motivation and subsequent business performance are influenced by a number of factors: personal predispositions, e.g. risk appetite [9], family background, social environment including peer sex [10], or environmental conditions [11]. 
Another factor of success is the level of education, which is reported as one of the major obstacles to starting a business. The Global Entrepreneurship Monitor study, which has also been conducted several times in the Czech Republic, annually states that education barrier is behind one-third of failures or more than $40 \%$ of unplanned business plans. [12]. In other words, education is one of many entrepreneurial competences.

Already in 2003, we can trace in the EU materials the effort to define business competencies and their development. The 2008 "Small Business Act" identified eight core competencies focusing on the knowledge-based economy. It emphasizes the need to extend practice-oriented learning and business-school partnerships. [13]

However, the resulting EntreComp model is just one of many attempts to determine which competencies are key to a successful business. Despite repeated efforts, there is no consensus. There is therefore no generally accepted set of entrepreneurial competences that would constitute the economic literacy of entrepreneurs.

Defining entrepreneurial competences is a never-ending dynamic process. Competences that may be considered significant at this time may not have been considered at all, while other competencies may be pushed to the background over time. [14] IT or logistics competences can be an example. This is a consequence of social and scientific and technological developments.

Current young generations prefer "safe" employment at public enterprises. [15] This phenomenon affects not only the Czech Republic, but also many other countries, such as the Balkans. Active support for the development of entrepreneurial competences goes hand in hand with entrepreneurial success. [16, 17] The development of entrepreneurial competences thus appears to be desirable on a transnational, national and regional scale. [18 $-21]$

Finding a set of entrepreneurial competences will make it possible to propose measures to improve the preparation of students, future entrepreneurs. The competence-based approach to education is one of the most significant changes implemented by the European Higher Education Area, with a shift from a content-centred model to a competence-based one, in which competences become the core element of the learning proces. [22] The competences included in graduate training will enable the generation will be ready to do business. Primary research can provide the necessary information to determine the current set of business competencies.

\section{Methods}

The article presents the partial results of the quantitative survey that took place in winter 2018-2019. This survey is part of an extensive research on the economics literacy of business entities. The research team consists of selected teachers of the Department of Business Economics and Management (BEM) at the School of Business Administration in Karviná and selected students, mostly doctoral forms of BEM studies. Within this extensive research, both qualitative and quantitative surveys were carried out.

Respondents were elected entrepreneurs who set up an enterprise that had been operating on the market as of 1 January 2018 for at least 3 years. Furthermore, it was required that the company had a positive turnover for 3 consecutive years and these entrepreneurs were required to keep their business running. Managers who did not establish an enterprise themselves were not of interest.

The research targeted companies with fewer than 250 employees. Large companies were not elected because there is a presumption that management in these companies is installed and does not have a personal history of the entrepreneur who founded his own business. 
In terms of legal form, self-employed persons and owners - managers of limited liability companies were selected. In other legal forms it can be assumed that they are headed by professional management. Enterprises were selected throughout the Czech Republic and in most business sectors.

From the database of business entities in the Czech Republic, 1 per mile of businesses that met the above criteria was randomly selected from each region. In total there were 1136 enterprises.

The method of questioning was chosen within the quantitative survey. A questionnaire was chosen as a query technique. Created questionnaire contained, in addition to the identification of issues, questions covering various areas in which the research team hypothesized that respondents could be classified as significant. The questions were focused on the issue of entrepreneurial competences and were divided into several blocks. One of them concerned business processes. It was ascertained whether entrepreneurs can correctly define selected complex areas of processes and whether these areas need to be generally known before starting a business. These were mainly the processes in the area of material flow management and human resources management. This article presents the respondents' views on logistics.

Before the data collection itself, a pilot survey was carried out. This phase of research cannot be overlooked as the academic language and the language of practice are not entirely identical. The pilot investigation revealed a lack of knowledge of professional terminology which would subsequently, and quite wrongly, result in a large number of 'do not know, I cannot assess' assessments. On the basis of this experience, the individual questions have been modified - in particular, with explanatory comments.

Closed questions focused on entrepreneurial competences were formulated in the form of ideas on which respondents expressed their opinion. The results were graded using the Likert scale as comparable to other sections of the questionnaire. Specifically: 1 - definitely not, 2 - probably not, 3 - probably yes, 4 - definitely yes, or I do not know, I cannot judge if they had no opinion on the question).

For modeling relationships basic statistical methods were used. Cramer's contingency coefficient $V$ which represents the most appropriate measure of association between two nominal variables was one of the most important. Scale, introduced by Cohen [23] was used for coefficient interpretation. For predictive interpretation the formulation, that can be found in the work of Liebetrau [24], was also used, where the degree of significance between 0.25 and 0.5 means a factor in the causal linkage and value between 0.7 and 0.9 makes it possible to predict the factor behavior in the next period.

In this text, respondents' opinions on distribution logistics are presented as one of the areas that a future entrepreneur should know if he wants to succeed. Research was conducted in order to determine:

- Determine whether to include basic knowledge of distribution logistics in business competencies.

- Determine whether there is an interaction between attitude to the importance of distribution logistics and gender

- Determine whether there is a link between attitude to distribution logistics and education.

- Determine whether there is a connection between attitude to distribution logistics and length of practice.

\section{Results and Discussion}

Out of the total number of 1136 addressed companies, 245 companies across the Czech Republic showed interest in cooperation. Answers to individual questions from the 
questionnaire were obtained on the basis of personal questioning. This ensured that fully completed questionnaires have been received. It took an average of 40 minutes to complete the questionnaire. This time corresponds to the scope of the questionnaire.

All 245 completed questionnaires were rewritten into the data matrix in MS Excel. MS Excel and SPSS were used to process the results. The total internal reliability was measured using Cronbach's alpha, which had value of 0.855 . Partial analyses internal reliability of data ranged around values 0.79 , which satisfies the condition for further data analysis. [25]

In terms of gender balance, 168 men and 77 women responded, which corresponds to the gender distribution in the business population in the Czech Republic. Concerning the age of respondents, the dominant group consists of entrepreneurs aged 41 to 55 years $(54.69 \%)$, followed by 26 to 40 years $(28.16 \%)$, the third ranked group 56 to 65 years $(11.84 \%)$. The age groups of 18 to 25 years and 65 years and over were represented by minority groups $(2.86$ and $2.45 \%$, respectively).

The distribution of respondents in terms of their highest education level was as follows: $40.00 \%$ of respondents have a secondary school leaving examination, $36.73 \%$ are university graduates, $19.59 \%$ have a vocational certificate, $3.27 \%$ are graduates of the higher vocational school, and the rest entrepreneurs have only basic education.

Regarding the length of the entrepreneurial practice of respondents, the dominant group consists of entrepreneurs with $20+$ years of experience $(43.27 \%), 25.71 \%$ of respondents have experience of up to 20 years, $24.49 \%$ have experience of up to 10 years. $6.53 \%$ of respondents showed the required minimum, i.e. 3 years of experience. In summary, a typical respondent was aged 41 to 55 years with more than 20 years of experience and at least a school-leaving certificate.

A total of 35 respondents were unable to answer the question of whether they need to have basic knowledge of distribution logistics before starting a business. These answers were not included in the average mark calculation. The distribution of answers by gender of respondents is shown in Table 1. This shows that ignorance is prevalent on the part of women (Cramer's $\mathrm{V}=0.264$ ). On the other hand, if women evaluated the importance of distribution logistics, they gave it a higher mark than men on average. In summary, basic knowledge of distribution logistics was rated by respondents as important.

Table 1. Evaluation of the importance of distribution logistics by gender

\begin{tabular}{|l|c|c|}
\hline & Men & Women \\
\hline Definitely NOT & $2.38 \%$ & $6.49 \%$ \\
\hline Rather NOT & $13.69 \%$ & $3.90 \%$ \\
\hline Rather YES & $48.21 \%$ & $37.66 \%$ \\
\hline Definitely YES & $26.19 \%$ & $27.27 \%$ \\
\hline I do not know & $9.52 \%$ & $24.68 \%$ \\
\hline Mean & 3.086 & 3.14 \\
\hline
\end{tabular}

Table 2 shows the attitude to the importance of distribution logistics according to respondents' education. In order to meet the prerequisites for the applicability of statistical tests, entrepreneurs with vocational certificate and basic education were merged, however, subjects with only basic education assigned the highest ranking to distribution logistics. The table also shows that respondents with the lowest education did not evaluate the importance of distribution logistics with the lowest possible number of points and that this group prevails that an entrepreneur needs to have basic knowledge of distribution logistics 
before starting a business. Although the group with higher vocational education did not choose "definitely NOT" rating, but due to the number of "rather NOT" ratings, the average rating in this group is less than 3 . What is also striking is the relatively high number of people with higher education who have not been able to assess the importance of distribution logistics. The dependence of the evaluation of the importance of distribution logistics on education was not confirmed (Cramer's V $=0.1$ ).

Table 2. The relationship between education and attitude to the importance of distribution logistics

\begin{tabular}{|l|c|c|c|c|}
\hline & $\begin{array}{c}\text { Primary and secondary } \\
\text { school with vocational } \\
\text { certificate }\end{array}$ & $\begin{array}{c}\text { Secondary } \\
\text { school with } \\
\text { GCSE }\end{array}$ & $\begin{array}{c}\text { Higher } \\
\text { vocational school }\end{array}$ & University \\
\hline $\begin{array}{l}\text { Definitely } \\
\text { NOT }\end{array}$ & $0.00 \%$ & $4.08 \%$ & $0.00 \%$ & $5.56 \%$ \\
\hline Rather NOT & $8.16 \%$ & $9.18 \%$ & $25.00 \%$ & $12.22 \%$ \\
\hline Rather YES & $46.94 \%$ & $44.90 \%$ & $50.00 \%$ & $43.33 \%$ \\
\hline Definitely YES & $34.69 \%$ & $26.53 \%$ & $12.50 \%$ & $23.33 \%$ \\
\hline I do not know & $10.20 \%$ & $15.31 \%$ & $12.50 \%$ & $15.56 \%$ \\
\hline Mean & 3.11 & 3.28 & 2.86 & 3 \\
\hline
\end{tabular}

The evaluation of the need to have a basic knowledge of distribution logistics according to the length of the respondent's practice is shown in Table 3 . This shows that subjects that do business only briefly consider it the least important. But they also gave it a relatively high score (2.83). In this group of entrepreneurs, the highest number of occurrences of the "I don't know" rating is also. Again, there was no link between the evaluation of the importance of distribution logistics and the length of practice (Cramer's $\mathrm{V}=0.12$ ).

Table 3. Evaluation of the importance of distribution logistics according to the length of practice

\begin{tabular}{|l|c|c|c|c|}
\hline & 3 years & Up to 10 years & Up to 20 years & $20+$ years \\
\hline Definitely NOT & $12.50 \%$ & $3.33 \%$ & $4.76 \%$ & $1.89 \%$ \\
\hline Rather NOT & $6.25 \%$ & $11.67 \%$ & $9.52 \%$ & $11.32 \%$ \\
\hline Rather YES & $37.50 \%$ & $45.00 \%$ & $50.79 \%$ & $42.45 \%$ \\
\hline Definitely YES & $18.75 \%$ & $25.00 \%$ & $25.40 \%$ & $29.25 \%$ \\
\hline I do not know & $25.00 \%$ & $15.00 \%$ & $9.52 \%$ & $15.09 \%$ \\
\hline Mean & 2.83 & 3.08 & 3.07 & 3.17 \\
\hline
\end{tabular}

In summary, the basic knowledge of distribution logistics was rated by the respondents as important, as the overall average score reached 3.1. It is therefore one of the competences that a future entrepreneur should be equipped with and when creating a model of economic literacy of current business entities in the Czech Republic it is necessary to work with this competence.

However, it should be pointed out that ignorance of professional terminology remains a problem. Without modifying the questionnaire, i.e. supplementing the problematic statements with explanatory notes, a different (worse) evaluation can be assumed. This can be seen as an impulse for the further direction of education. 


\section{Conclusion}

A prerequisite for success is to be equipped with a set of specific competencies. The same goes for entrepreneurship. The universal set of entrepreneurial competences does not exist and cannot exist. In addition, this set of competencies changes over time in response to a changing business environment. Determining the set of entrepreneurial competencies needed to set up a successful entrepreneurship is necessarily based on primary research.

The article presents partial results of an extensive survey conducted in the Czech Republic on this topic. The presented results are based on quantitative research carried out between successful self-employed persons and executives - owners of successful limited liability companies. The questionnaire survey in the matter of distribution logistics showed that current successful entrepreneurs clearly included its basic knowledge in the set of business competencies. The respondents agreed on this view regardless of their education or the length of their business practice. A slight causality has been found between the attitude to the importance of basic knowledge of distribution logistics and gender, but this is only a measure of importance, since both sexes have no doubt about including distribution logistics in the system of entrepreneurial competences.

Basic knowledge of distribution logistics is just one of many competencies that a current entrepreneur should be equipped with in order to be successful. This reflects the fact that it is not enough to produce an interesting product, but that it is necessary to physically reach the customer and that the current entrepreneurs are fully aware of this fact.

The quantitative research, whose partial results presents this paper, was complemented by qualitative research. Both types of research will be compared. Further written outputs will bring results concerning other entrepreneurial competencies with the aim of creating a competency model that would reflect the economic literacy of current business entities.

This work was supported by the Silesian University in Opava, by the Student Grant System SGS/06/2018 "Economics Literacy of Business Entities".

\section{References}

1. J.-P. Rodrigue, Transportation and the geographical and functional integration of global production networks. Growth and Channge 37, 4 (2006)

2. G. Marino, G. Zotteri, F. Montagna, F., Consumer sensitivity to delivery lead time: a furniture retail case. International Journal of Physical Distribution \& Logistics Management 48, 6 (2018)

3. T. Gong, Y. Yi, The effect of service quality on customer satisfaction, loyalty, and happiness in five Asian countries. Psychology \& Marketing 35, 6 (2018)

4. IMF, Globalization: Threat or Opportunity? (2002)

5. T. C. Onstein, L. A. Tavasszy, D. A. van Damme, Factors determining distribution structure decisions in logistics: a literature review and research agenda. Transport Reviews 39, 2 (2019)

6. S. Mohd-Ramly, N. Omar, Exploring the influence of store attributes on customer experience and customer engagement. International Journal of Retail \& Distribution Management 45, 11 (2017)

7. M. J. Maloni, C. R. Carter, Opportunities for Research in Third-Party Logistics. Transport Journal 45, 2 (2006)

8. K. L. Hancock, Freight transport and distribution: concepts and optimisation models. Transport Reviews 39, 4 (2019)

9. M. A. Lopera, S. Marchand, Peer effects and risk-taking among entrepreneurs: Lab-inthe-field evidence. Journal of Economic Behavior \& Organization 150 (2018) 
10. S. Markussen, K. Røed, The gender gap in entrepreneurship - The role of peer effects. Journal of Economic Behavior \& Organization 134 (2017)

11. D. A. Shepherd, K. Wennberg, R. Suddaby, J. Wiklund, What Are We Explaining? A Review and Agenda on Initiating, Engaging, Performing, and Contextualizing Entrepreneurship. Journal of Management 45, 1 (2019)

12. M. Lukeš, M. Jakl, Podnikání v České republice (Oeconomica, Praha, (2012)

13. EU commision, Akční plán: Financování udržitelného růstu (2016)

14. Š. Čemerková, L. Čespivová, Working Paper in Interdisciplinary Economics and Business Research no. 61. (Silesian University in Opava, School of Business Administration in Karviná, Karviná, 2018)

15. J. Jovanovic, Z. Krivokapić, A. Vujović, Rebus Approach of Entrepreneurship Learning. 2018 ENTRENOVA Conference Proceedings (2018)

16. M. Bacigalupo, P. Kampylis, Y. Punie, G. Van den Brandeal, EntreComp: The Entrepreneurship Competence Framework (Publication Office of the European Union, Luxembourg, 2016)

17. Komarkova, J. Connrads, A. Collado, Entrepreneurship Competence: An Overview of Existing Concepts, Policies and Initiatives. In-depth case study report. JRC Technical Reports (Publications Office of the European Union, Luxembourg, 2015)

18. A. Fayolle, B. Gailly, N. Lassas-Clerc, Assessing the impact of entrepreneurship education programmes: A new methodology. Journal of European Industrial Training 30, 9 (2006)

19. G. Graevenitz, D. Harhoff, R. Weber, The effects of entrepreneurship education. Journal of Economic Behavior \& Organization 76, 1 (2010)

20. J. Šebestová, The conflict between strategic method application and theoretical knowledge in small and medium sized companies: The case of the Czech Republic. Business: Theory and Practice /Verslas: Teorija ir Praktika 17, 2 (2016)

21. R. Weber, Evaluating entrepreneurship education (Springer, Munich, 2011)

22. R. Ferreras-Garcia, A. Hernández-Lara, E. Serradell-López, Entrepreneurial competences in a higher education business plan course. Education + Training 61, 7/8 (2019)

23. Cohen, Statistical power analysis for the behavioral sciences (L. Erlbaum Associates, New Jersey, 1988)

24. A. M. Liebetrau. Measures of association. (Quantitative Applications in the Social Sciences Series) (Sage Publications, Newbury Park,1983)

25. J. C. Nunnally, Psychometric Theory (McGraw-Hill, New York, 1978) 